\title{
HUBUNGAN ANTARA DISMENOREA PRIMER DENGAN KUALITAS TIDUR MAHASISWI PSIK STIKES MUHAMMADIYAH PALEMBANG
}

\author{
Yuniza', Puji Fitrianti Putri Anandez ${ }^{2}$, Siti Romadoni ${ }^{3}$ \\ Program Studi Ilmu Keperawatan STIKes Muhammadiyah Palembang \\ Email: niza.yun@yahoo.com
}

\begin{abstract}
ABSTRAK
Latar belakang: kejadian dismenorea primer dapat mempengaruhi kualitas tidur menjadi buruk karena peningkatan kadar prostagladin memiliki efek meningkatkan kontraktilitas otot uterus, vasokonstriksi dan mengakibatkan iskemia pada otot uterus, sehingga terjadinya nyeri saat menstruasi. Tujuan: Mengetahui Hubungan Antara Dismenorea Primer Dengan Kualitas Tidur Mahasiswi PSIK STIKes Muhammadiyah Palembang. Metode:Desain Penelitian yang digunakan yaitu cross-sectional dengan kuesioner dismenorea primer dan Pittsburgh Sleep Quality Index (PSQI). Teknik sampling yang digunakan yaitu total sampling dengan jumlah sampel 342 responden, dengan uji statistik Chi Square. Kesimpulan:Berdasarkan hasil uji statistik diketahui bahwa nilai $p$ value $(0,000)<\alpha=0$, 05. Ada hubungan antara dismenorea primer dengan kualitas tidur mahasiswi PSIK STIKes Muhammadiyah Palembang.
\end{abstract}

\section{Kata Kunci : Dismenorea Pimer, Kualitas Tidur}

\section{ABSTRACT}

The incidence of primary dysmenorrhea results in poor sleep quality because increased levels of prostaglandin has an effect of increasing contractility of the uterine muscle and vasoconstriction and resulting in ischemia in the uterine muscle so that pain during menstruation occurs. To find out the relationship between primary dysmenorrhea and sleep quality of PSIK female students of Muhammadiyah Institute of Health Science of Palembang. This study used cross sectional design with Pittsburgh Sleep Quality Index (PSQI). The number of samples was 342 respondents taken using total sampling technique. The statistical used was chi-square test. The statistical test results showed that $p$ value obtained was $(0,000)<\alpha=0,05$. There was a relationship between primary dysmenorrhea and sleep quality of PSIK female students of Muhammadiyah Institute of Health Science.

\section{Keywords : Primary Dysmenorrhea, Sleep Quality}

\section{PENDAHULUAN}

Kesehatan reproduksi memiliki peranan penting terhadap remaja, karena dalam tahap remaja terjadi perubahan psikologis untuk menemukan jati dirinya. Pada masa peralihan tersebut, seorang remaja akan mengembangkan bakat dan kemampuan yang dimiliki yang akan ditunjukan pada orang lain agar terlihat berbeda dari pada orang lain (Kusmiran, 2011).

Masalah yang terjadi pada kesehatan reproduksi remaja salah satunya adalah gangguan saat menstruasi. Menstruasi merupakan salah satu tanda dari perubahan yang terkait dengan kematangan seksual pada masa pubertas 2 (Manuaba, 2010 ).

Setiap wanita akan mengalami menstruasi, menstruasi ini bisa disertai 
dengan nyeri atau tidak. Nyeri haid/dismenorea merupakan ketidakseimbangan hormon progesteron dalam darah sehingga mengakibatkan rasa nyeri timbul, faktor psikologis juga ikut berperan terjadinya dismenore pada beberapa wanita (Anna, 2009).

Menurut Hendra (2008) Dismenorea primer merupakan dismenorea yang terjadi sejak usia pertama sekali datang haid yang disebabkan oleh faktor intrinsic uterus, berhubungan erat dengan ketidakseimbangan hormone steroid seks ovarium tanpa adanya kelainan organic dalam pelvis. Terjadi pada usia remaja, dan dalam 2-5 tahun setelah pertama kali haid (menarchea).

Kejadian dismenore di Indonesia juga tidak kalah tinggi dibandingkan dengan negara lain di dunia. Menurut Proverawati \& Misaroh (2012) di Indonesia angka kejadian dismenore terdiri dari $72,89 \%$ dismenore primer dan $21,11 \%$ dismenore sekunder dan angka kejadian dismenore berkisar $45-95 \%$ di kalangan perempuan usia produktif.

Menurut Laila (2011) faktor yang menyebabkan dismenorea primer terjadi diantaranya faktor psikologis, faktor konstitusi, faktor endokrin atau hormon dan faktor alergi. Menurut teori Sartika(2011) faktor resiko terjadinya dismenorea primer yaitu genetik, stress yang berlebihan, olahraga yang tidak teratur, usia menarche yang kurang dari 12 tahun.

Munculnya rasa nyeri tersebut meluas hingga ke pinggang, punggung bagian bawah dan paha akan menimbulkan masalah keperawatan dan mengganggu kebutuhan dasar manusia salah satu diantaranya adalah tidur. Tidur yang tidak kurang dan kualitas tidur buruk dapat mengakibatkan gangguan fisiologi dan psikologi. Dampak fisiologi diantaranya penurunan aktivitas sehari-hari, lemah, daya tahan tubuh menurun dan ketidakstabilan tanda-tanda vital. Sedangkan dampak psikologis diantaranya depresi, cemas dan tidak konsentrasi sehingga dapat menggangu aktivitas. (Bukit, 2013).

Adapun faktor-faktor yang mempengaruhi kualitas tidur menurut Alimul (2015) yaitu : penyakit, lingkungan, latihan fisik dan kelelahan, obat-obatan dan zat kimia, diet dan kalori serta stres psikologis.

Menurut teori Kozier Erb, Berman dan Snyde (2004), nyeri dapat menimbulkan penurunan kapasitas vital paru, FRC dan timbulnya hipoksemia sehingga tubuh melakukan kompensasi dengan meningkatkan frekuensi nafas untuk memenuhi kebutuhan oksigen tubuh. Sehingga nafas yang pendek ini dapat mengganggu saat tidur.

Berdasarkan studi pendahuluan yang dilakukan di STIKes Muhammadiyah palembang pada seluruh mahasiswi PSIK semester 2, 4, 6 dan 8 dengan jumlah 342 mahasiswi mengatakan saat menstruasi datang merasakan nyeri dan menggangu kualitas tidur dan ada juga mahasiswi yang mengatakan bahwa dengan tidur nyeri tersebut bisa berkurang.

\section{METODOLOGI PENELITIAN}

Jenis penelitian yang digunakan yaitu penelitian kuantitatif dengan pendekatan cross-sectional. Sampel dalam penelitian sebanyak 342 responden dengan metode pengambilan sampel yaitu total sampling. Penelitian dilakukan di STIKes Muhammadiyah Palembang pada prodi S1 Keperawatan. 


\section{HASIL PENELITIAN}

\section{Analisa Univariat}

Tabel 1. Rata -rata Umur

\begin{tabular}{ccccc}
$\begin{array}{c}\text { Karakte } \\
\text { ristik }\end{array}$ & Mean & $\begin{array}{c}\text { Medi } \\
\text { an }\end{array}$ & Min & Max \\
\hline Umur 19,74 & $\begin{array}{r}20, \\
00\end{array}$ & 17 & 39
\end{tabular}

Dari tabel 1 diatas menunjukkan bahwa nilai rata-rata umur responden dengan nilai median 20,00 , usia minimal 17 tahun dan usia maksimal 38 tahun.
Tabel 2. Distribusi Frekuensi Disminorea Primer Dan Kualitas Tidur

\begin{tabular}{lllll}
\hline No & Variabel & Kategori & \multicolumn{1}{c}{ N } & \multicolumn{1}{c}{$\%$} \\
\hline 1 & Dismenorea & Ya & 327 & $95,6 \%$ \\
& primer & Tidak & 15 & $4,4 \%$ \\
& & Jumlah & 342 & $100 \%$ \\
2 & Kualitas & Ya & 317 & $82,7 \%$ \\
& Tidur & Tidak & 25 & $7,3 \%$ \\
& & Jumlah & 342 & $100 \%$
\end{tabular}

Dari tabel 2 menunjukkan bahwa dari 342 responden sebagian besar mengalami dismenorea primer sebanyak 327 responden $(95,6 \%)$. Untuk kualitas tidur menunjukkan bahwa dari 342 responden sebagian besar mengalami kualitas tidur yang buruk sebanyak 317 responden (92,7\%).

\section{Analisa Bivariat}

Tabel 3. Hubungan Antara Dismenorea Primer Dengan Kualitas Tidur

\begin{tabular}{|c|c|c|c|c|c|}
\hline \multirow[b]{2}{*}{ Disminore Primer } & \multicolumn{2}{|c|}{ Kualitas Tidur } & \multirow[b]{2}{*}{$\begin{array}{c}\text { Total } \\
\mathbf{n}\end{array}$} & \multirow[b]{2}{*}{ Pvalue } & \multirow[b]{2}{*}{ OR } \\
\hline & $\frac{\text { Buruk }}{\mathrm{N}}$ & $\begin{array}{c}\text { Baik } \\
N\end{array}$ & & & \\
\hline Ya Disminore Primer & 309 & 18 & 327 & 0,000 & 15,021 \\
\hline $\begin{array}{ll}\text { Tidak } & \text { Disminore } \\
\text { Primer } & \end{array}$ & 8 & 7 & 15 & & \\
\hline
\end{tabular}

Berdasarkan tabel 3 diatas menunjukkan hasil analisis hubungan dismenorea primer dengan kualitas tidur diperoleh bahwa ada 327 responden dari 342 responden yang mengalami dismenorea primer dengan kualitas tidur yang buruk sebanyak 309 responden.

Berdasarkan hasil analisa statistik dengan mengunakan uji Chi-Square didapat nilai $p$ value $(0,000)<\alpha=0,05$, maka dinyatakan ada hubungan antara dismenorea primer dengan kualitas tidur mahasiswi PSIK STIKes Muhammadiyah Palembang.
Berdasarkan hasil analisis, didapatkan juga nilai OR 15, 021 mahasiswi yang tidak mengalami dismenorea primer memilki peluang 15, 021 kali untuk memiliki kualitas tidur yang baik.

\section{PEMBAHASAN}

Dari hasil analisa distribusi frekuensi diketahui bahwa sebagian besar mahasiswi PSIK yang mengalami dismenorea primer sebanyak 327 responden dan yang tidak mengalami dismenorea primer sebanyak 15 responden. Dan yang mengalami dismenorea primer dengan kualitas tidur 
baik sebanyak 18 responden dan yang mengalami dismenorea primer dengan kualitas tidur buruk sebanyak 309 responden.

Menurut Laila (2011) faktor yang menyebabkan dismenorea primer terjadi diantaranya faktor psikologis, faktor konstitusi, faktor endokrin atau hormon dan faktor alergi. Menurut teori Sartika(2011) faktor resiko terjadinya dismenorea primer yaitu genetik, stress yang berlebihan, olahraga yang tidak teratur, usia menarche yang kurang dari 12 tahun.

Berdasarkan konsep teori diatas, peneliti berpendapat dismenorea primer adalah nyeri yang dirasakan pasa saat menstruasi datang, ditandai dengan kram dan nyeri dibagian perut, dan sebagian juga ada yang mengalami mual dan muntah dan ada juga yang tidak. Dismenorea primer ini merupakan nyeri menstruasi tanpa adanya kelainan pada sistem reproduksi.

\section{Kualitas Tidur}

Dari hasil analisa distribusi frekuensi didapatkan yang mengalami kualitas tidur baik sebanyak 25 orang dan yang mengalami kualitas tidur buruk sebanyak 317 responden. diketahui sebagian besar mahasiswi yang mengalami dismenorea primer dengan kualitas tidur yang baik sebanyak 18 responden dan yang mengalami dismenorea primer dengan kualitas tidur yang buruk sebanyak 309 responden.

Menurut teori Potter dan Perry (2009) Kualitas tidur adalah ukuran dimana seseorang itu dapat kemudahan dalam memulai tidur dan untuk mempertahankan tidur, kualitas tidur seseorang dapat digambarkan dengan lama waktu tidur, dan keluhan - keluhan yang dirasakan saat tidur ataupun sehabis bangun tidur. Kebutuhan tidur yang cukup ditentukan selain oleh faktor jumlah jam tidur (kuantitas tidur), juga oleh faktor kedalaman tidur (kualitas tidur).

Berdasarkan teori diatas peneliti berpendapat bahwa kualitas tidur merupakan ukuran saat seseorang cukupnya jam tidur. Seseorang dengan dismenorea primer akan mengalami gangguan dalam tidurnya karena terjadinya nyeri saat menstruasi.

Hasil analisa bivariat uji Chi-Square didapat $(p$ value $=0,000<0,05)$, maka dinyatakan ada hubungan antara dismenorea primer dengan kualitas tidur mahasiswi PSIK STIKes Muhammadiyah Palembang.

Hasil penelitian ini sejalan dengan Nada dan listyawati (2017), menyatakan bahwa adanya hubungan yang lemah namun signifikan antara efikasi diri dengan kualitas tidur pada remaja yang mengalami dismenorea. Hubungan yang lemah disebabkan karena terdapat beberapa faktor lainnya yang lebih kuat, sehingga menyebabkan remaja yang menderita dismenore memiliki kualitas tidur yang buruk.

Menurut teori Potter dan Perry (2009) Kualitas tidur adalah ukuran dimana seseorang itu dapat kemudahan dalam memulai tidur dan untuk mempertahankan tidur, kualitas tidur seseorang dapat digambarkan dengan lama waktu tidur, dan keluhan - keluhan yang dirasakan saat tidur ataupun sehabis bangun tidur. Kebutuhan tidur yang cukup ditentukan selain oleh faktor jumlah jam tidur (kuantitas tidur), juga oleh faktor kedalaman tidur (kualitas tidur).

Menurut teori Kozier Erb, Berman dan Snyde (2004), nyeri dapat menimbulkan penurunan kapasitas vital paru, FRC dan timbulnya hipoksemia sehingga tubuh melakukan kompensasi dengan meningkatkan frekuensi nafas untuk memenuhi kebutuhan oksigen tubuh. 
Sehingga nafas yang pendek ini dapat mengganggu saat tidur

Berdasarkan konsep teori dan hasil penelitian diatas, peneliti berpendapat bahwa dismenorea primer dapat mempengaruhi kualitas tidur menjadi buruk karena terjadinya nyeri saat menstruasi.

\section{KESIMPULAN}

Berdasarkan hasil penelitian yang dilakukan di STIKes Muhammadiyah Palembang pada Program Studi IImu Keperawatan (PSIK) semester 2, 4, 6, dan 8, mengenai hubungan antara dismenorea primer dengan kualitas tidur pada tanggal 10 - 16 Mei 2019 maka dapat ditarik kesimpulan sebagai berikut:

1. Distribusi Frekuensi Dismenorea Primer sebagian besar yang mengalami dismenorea primer sebanyak 327 responden dan yang tidak mengalami dismenorea primer sebanyak 15 responden

2. Distribusi Frekuensi Kualitas Tidur sebagian besar yang mengalami kualitas tidur yang buruk sebanyak 317 responden dan kualitas tidur yang baik sebanyak 25 responden.

3. Ada Hubungan Antara Dismenorea Primer dengan Kualitas Tidur Mahasiswi PSIK STIKes Muhammadiyah Palembang dengan nilai $p$ value $(0,000)<\alpha=0,05$.

\section{SARAN}

Berdasarkan kesimpulan diatas, peneliti memberikan saran diantaranya:

\section{Bagi STIKes Muhammadiyah Palembang}

Diharapkan kepada institusi pendidikan khususnya prodi PSIK Muhammadiyah Palembang. untuk mengembangkan ilmu mengenai dismenorea primer dengan kualitas tidur

\section{Bagi Mahasiswi PSIK STIKes Muhammadiyah Palembang}

Diharapkan kepada Mahasiswi untuk menambah dan menggali lagi ilmu yang berhubungan dengan dismenorea primer serta kualitas tidur. Dan mengetahui cara bagaimana mengurangi nyeri dismenorea primer dengan cara non farmakologi yaitu yoga, self tapping, senam dismenorea, teknik nafas dalam, agar tidak mengalami kualitas tidur yang buruk saat terjadinya dismenorea primer

\section{Bagi peneliti selanjutnya}

Penelitian ini dapat dikembangkan dengan jumlah sampel yang berbeda, metodologi dan desain yang berbeda, lokasi yang berbeda serta, penambahan variabel. Sehingga dapat menambah ilmu pengetahuan yang lebih dalam mengetahui hubungan antara dismenorea primer dengan kualitas tidur mahasiswi.

\section{DAFTAR PUSTAKA}

Annathayakeisha. (2009). Nyeri Haid. Diakses tanggal 18 Oktober2012.

Atikah Proverawati dan Siti Misaroh.2009. Menarche Menstruasi Pertama Penuh Makna. Yogyakarta: Nuha Medika.

Bukit, E. (2013). Sleep Quality and Factors Interfering with Sleep among Hospitalized Elderly in Medical Units, Medan, Indonesia. Prince of Songkla University

Hendra, AW. 2008. Faktor-Faktor Yang Mempengaruhi Pengetahuan. Avaible : http: //ajang-berkarya. Wordpress. com/ 2008/ 06/ 07/ Konsep Pengetahuan/ 17/ 05/ 2011

Kusmiran, Eny. 2011. Reproduksi Remaja dan Wanita.Jakarta:Salemba Medika.

Kozier, B., et al. 2004. Fundamental of Nursing: Concepts, Process and 
Practice. (7th ed). New Jersey:

Prentice -Hall, Inc.

Laila Nur Najmi (2011). Buku Pintra

Menstruasi. Yogyakarta : Buku Biru

Manuaba, IAC., I Bagus, dan IB Gde. 2010.

IImu Kebidanan, Penyakit Kandungan

dan KB untuk Pendidikan Bidan.

Edisi kedua. Jakarta: EGC

Sartika, Sabhiyana 2011. Hubungan Status Gizi dan Usia Menarche pada

$\begin{array}{llll}\text { Siswa Kelas IX SMPN } 87 & 87\end{array}$ Jakarta.http://library.upnvj.ac.id/index .php?p=show_detail\&id=8238

diakses senin 24 0ktober 2012. 